\title{
THE PUBLIC WELFARE AND THE HOLDING COMPANY
}

\author{
By J. P. Goodrich, \\ Director, National City Bank, \\ Indianapolis, Ind.
}

I hold no brief for or against holding companies: That there are good as well as bad holding companies will be conceded. Some have been conducted along right lines and been powerful agencies in the development of our public utilities. Others have degenerated into mere schemes to multiply securities and sell them to confiding investors without any resultant benefit to the general public. $\mathrm{My}$ purpose is to point out some dangers to the public welfare that arise from the operation of holding companies.

Mr. Mead, in his recent work on "Corporation Finance," defines a holding company to be "a corporation organized for the purpose of acquiring the stock and other securities of other corporations" and states that "The primary purpose of such corporations is to effect a combination of allied enterprise which cannot be accomplished by the use of any one of the corporations it was intended to include."

In a recent conversation with a gentleman who had served a long and honorable career on the bench and is now one of the leading members of a public service commission in one of the states, $I$ asked him to define a "holding company." He replied: "A holding company is a corporation created for the purpose of separating a gullible public from their money by the sale of watered stocks."

While I do not at all agree with the judge's definition, yet I am quite certain he expressed the prevailing opinion of the average man who has given no special consideration to the subject.

Perhaps the first real holding company of large size was the Pennsylvania Company, organized in 1870. Its purpose was to centralize the control of the Pennsylvania railway lines west of Erie and Pittsburgh. Its charter specifically authorized it to "make purchases and sales for investment in the bonds and securities of other companies." The owning by railroads of stock in other companies has been a common practice for the past fifty years, yet holding com- 
panies as we commonly use the term are of comparatively recent creation.

Prior to 1888 the laws of no state clearly authorized the creation of corporations, the principal object of which was to own stocks and securities of other corporations, but when the legislative intent on that subject was expressed at all, such ownership was prohibited.

In 1888, when the corporation laws of New Jersey were revised, authority was granted to organize corporations for the general purpose of owning the stocks and securities of other corporations and from the enactment of these laws can be traced the origin of the modern holding company.

After the dissolution of the standard oil and other trusts by the courts, those interested in such properties began to look around for some method by which the same object might be accomplishedby which they might do indirectly what the courts had said could not be done directly. They found in the revised corporation laws of New Jersey the exact authority needed to accomplish their purpose and proceeded to organize under those laws. New Jersey soon earned the distinction of being the "mother of trusts," and she was, indeed, a fruitful mother-the trusts big and little sought the protecting aegis of her laws and the revenues derived from this source soon contributed largely to the support of the state.

Not to be outdone by one of the sister states and being unwilling to see many of their domestic corporations surrender their charters and change their domicile to New Jersey, the other states adopted a similar practice, and many of them were soon bidding one against the other for the patronage of these corporations, which increased with marvelous rapidity and covered every line of manufacturing and commerce. The government soon began its relentless war on those holding companies, which, in its opinion, transgressed the provisions of the Sherman anti-trust law; the process of "unscrambling the eggs" is now well under way and those who desire to do so can easily keep within the law in the organization of companies of this character and in the conduct of big business.

Our special interest this evening is with respect to holding companies operating in the field of public service corporations other than railroads. When I speak of a holding company, I mean a holding company as defined by Mead, and do not refer to an "owning" or "management company"-to a corporation owning the corpus of 
various public utilities, which supply from a central station many communities with light, heat, power and interurban railway connection. Such organizations are not holding companies in any sense of the term and no possible objection can be urged to them.

The holding company is comparatively a late comer in the field of public service corporations; while there were isolated cases prior to 1898 , the great majority of holding companies have been organized within the last ten or twelve years. The rapid growth, both in number and extent, of public service corporations; the wonderful improvement in electrical machinery; the constantly widening area that could be supplied economically with electric energy and gas from a central station; and the steadily decreasing cost of the production of these modern necessities presented a most inviting field to men of large vision, who were not slow to enter and possess the land, through the agency of holding companies, and appropriate the fruits thereof to their own use. Plants operated separately at a loss or little profit, when joined together by transmission lines and supplied from a central station under the management of trained experts, returned handsome profits to the promoters, gave better service to the public and encouraged a wider use of their products.

This development has been by no means confined to holding companies, but the same degree of progress has been made by "owning" and "management companies." A large part of this development, however, has been by holding companies, as it was not only the simplest and easiest way of accomplishing the result, but promised greater profits to the promoters, with no limitation on the amount or character of the securities to be issued, except their own judgment as to what the earnings of operating companies would justify, and as to what the bankers, underwriting the issues, would be willing to sell.

The growth of holding companies in this field is strikingly shown by Mr. Gibbony in his testimony before the Senate committee when he stated that of the eight billion of public service securities outstanding, over five and one-half billion is held by holding companies. $\mathrm{He}$ also stated that over three hundred million of holding companies' securities were sold abroad last year. It further appears from the testimony before the committee that one-half of all the street railway mileage in the United States and more than thirty per cent of all the electric central station plants are under the control of and are being operated by holding companies. 
Holding companies operating in the field of public utilities are not subject to the same criticism that resulted in the dissolution by the government of holding companies operating in other fields, for they are natural monopolies and competition is never desirable either from the standpoint of the public or of the investor. The public has learned from sad experience that, in the end, it is compelled to pay for unnecessary and unwise duplication of plants. For competition has been substituted public supervision of rates and security issues and, at this time, thirty of the states have in some form passed laws creating commissions to supervise public service corporations. Regulatory bodies usually are possessed with power to fix or approve rates; to regulate stock issues and to issue a writ of necessity as a condition precedent to the right to construct and operate a public utility.

The advantages claimed for holding companies, by their advocates, may be summed up under two general heads: (1) Greater operating efficiency, more efficient engineering and legal departments and more economical conduct of their purchasing departments; (2) Wider banking facilities and greater ability to market securities and finance the needs of subsidiaries.

It will be conceded, subject to certain limitations hereinafter noted, that, in the operating, engineering, management and legal departments, the holding companies possess certain advantages not possessed by small companies operating isolated plants-that there is a distinct advantage in any given territorial unit to join all the separate plants by transmission lines and serve them from a central station. In this way, the service of many employees may be dispensed with by the abandonment of the small stations; villages too small for a separate plant can be served; towns too small for continuous service can have the benefit of constant service previously enjoyed only by the larger cities; farmers along the line can and do avail themselves of the opportunity to use electric current for domestic and farm use; the load factor is greatly improved by reason of the diversified industries of the various communities served; an efficient engineering and repair corps may be retained and a system of comparative tests can be installed, so that, by reports and inspections, the most perfect and economic devices can be enjoyed in common and the performance of one plant used as a check on others, resulting in a competition of service, calculated to keep the local 
management in charge of each plant keyed to the highest point of efficiency with the result that the revenues are greatly increased and the operating expenses decreased to a degree hardly appreciated by those not acquainted with the actual facts. These advantages, however, are not peculiar to the holding company. Every advantage claimed for the holding company can be obtained and is being obtained by owning companies, operating central plants and supplying the territory naturally tributary thereto. One of the best operated street railway plants in the United States, the Twin City Rapid Transit, is not owned or controlled by a holding company. The gas company giving as good service as any and operating with the lowest rates in our country, the Citizens Gas of Indianapolis, is neither owned nor controlled by a holding company. There is scarcely a state in the Union that does not have central station plants not controlled by holding companies, accomplishing all the things claimed for holding companies.

To illustrate by a concrete example: We have in the city of Indianapolis two lighting companies-the Indianapolis Light and Heat Company, operated independently, and the Merchants Heat and Light Company, operated by the Merchants Public Utilities Company, the stock of which is in turn owned by the American Public Utilities Company.

For the year ending June 30, 1914, the independent company's operating expense, exclusive of depreciation charges, was 54 per cent of its gross, while the Merchants company, operated by the holding company, was operated at $53 \frac{1}{2}$ per cent, practically the same ratio as the other and showing no special operating efficiency for the holding company over the privately-owned company.

The Indianapolis, Columbus and Southern Traction Company in 1912 was leased by the Interstate Public Service Company, a holding company, which is in turn controlled by the Middle West Utilities Company. During the last year of its operation as an independent and detached unit or, for the year ending June 30, 1912, with a gross revenue of $\$ 421,433.36, \$ 208,673.56$ was saved for net. For the year ending June 30, 1914, under the operation of the Middle West Utilities Company, with a gross operating revenue of \$423,116.47 , only $\$ 184,244.35$ was saved as net operating revenue, showing an increase in this case of 10 per cent in operating expenses and a decrease of 12 per cent in net revenue. 
While I realize that we are not justified in reaching any general conclusion from the two cases cited, yet it is apparent here, at least, that the privately-operated utilities compare most favorably with those operated by the holding company. I am entirely satisfied that, given the same general conditions, it will be found that the utility. operated and conducted by its owners will compare most favorably with the utility operated through or by a holding company. Of course, it must be conceded that the purchaser in large quantities has an advantage over the small purchaser as to prices and selling conditions; yet, the larger the growth of these companies, the greater is the temptation of those who control them to interest themselves in the sources from which they obtain their supplies through stock ownership or some other method. This has become so prevalent in the railroad world that the government in its recent regulatory law has found it necessary to insert a section for the purpose of prohibiting such practice and it is not unreasonable to expect the same tendency to appear in the management of holding companies.

It is asserted that the operation of utilities by holding companies has resulted in reduced rates, and figures are given in support of this assertion. Yet an examination of the record shows that this reduction has been at the competitive point only and is by no means due to holding companies. What I mean by competitive point is that the reduction has come to the larger consumers of light and power with sufficient demand to justify the installation of a private plant and in order to get the business it has been found necessary to make a rate low enough to meet the cost of production by the private plant which has, in turn, brought a similar reduction to other large users of light and power.

A proportionate reduction has not been made to private consumers who are paying substantially the same rates they did before the holding companies entered the utility field.

That the holding company has a decided advantage in financial opportunities over the smaller operating companies is apparent. The holding company, on account of its superior banking facilities, its affiliation with large financial institutions having a world-wide market, should be able to market its securities on the most favorable terms, and at times when the small local plant must fail completely.

The holding company claims the further advantage that it does 
not have to appeal to regulatory bodies for permission to issue its securities, but can issue and dispose of them without any outside interference. While this may be desirable from the standpoint of the promoters of holding companies, yet it cannot be in the interest either of the investing public who purchase the securities or of those who consume the product of its subsidiaries.

It is now almost universally conceded that the public interest requires the supervision of the issues of securities of all public service corporations. Yet the holding company whose only source of income is from the stocks and bonds of its subsidiaries, which are under the control of regulatory bodies, claims to have and does have the right to issue and sell its securities without such supervision.

It is argued, inasmuch as the subsidiaries are controlled by regulatory bodies, which fix the amount of stocks, bonds and other securities to be issued, the price at which they can be sold, and which also determine the way in which money received can be expended, that, therefore, it is impossible for the owners of the utility to operate them except for the good of the public and that the conduct of the holding company in the issue and sale of its securities can be of no concern to the public. With this contention I cannot agree. There are interests involved other than that of the operating company and that of the immedite community served. The exercise by the state of the power to regulate stock and bond issues of public utilities is not necessary in the interest of the consumer unless the outstanding securities are to have some influence on rates. The state exercises this power not for that reason alone, but for the far stronger reason, that because they are public service corporations, the state owes a duty to the public to see to it that the securities issued bear some relation to the value of the property charged with a public use. The credit and good faith of the entire country is involved. These securities are issued under the sanction of a charter issued by one of the sovereign states - five and one-half billion of them have already been sold-over three hundred million of them were sold abroad last year and four hundred million are being marketed each year. If the present ratio of growth continues, within twenty years, the amount of such securities will exceed the total amount of railway securities now outstanding.

Mr. Homer in his address on this subject last March stated that "the national banks of the country had 13.4 per cent of their 
investment holdings in utility issues." Life insurance companies and savings institutions are turning more and more to these securities for their investments; and their policy holders and depositors and the general investing public are deeply interested in the safety and stability of holding company issues. The value of these securities rests wholly upon the earning power of the operating units which are under the control, in a large measure, of the regulatory body in charge.

The tendency to over-issue holding company securities is ever present. The profits of the promoters of these companies are fixed in a large measure by the amount they can issue and sell. Human nature is pretty much the same everywhere and it will be strange, indeed, if time does not demonstrate undue liberality in the issue of such securities.

This tendency is very clearly illustrated by two typical cases in my own state. The Merchants Heat and Light Company of Indianapolis, Indiana, was purchased in 1912 by the Merchants Public Utilities Company. At the time of the purchase there were outstanding $\$ 3,049,000$ of bonds and $\$ 1,500,000$ of common stock. This common stock was purchased by the Merchants Public Utilities Company at 60 per cent of its par value.

There was issued by the Merchants Public Utilities Company as a part of the transaction $\$ 2,000,000$ of common stock and $\$ 1,100,000$ of 6 per cent cumulative preferred stock. The common stock was in turn purchased by the American Public Utilities Company and what securities, if any, of the American Public Utilities Company were issued in payment of this does not appear from the record, but at any rate one and one-half million of common stock of the original operating company was represented by at least double that amount of new securities in the hands of the subsidiary holding company.

The Indianapolis, Columbus and Southern Traction line extending from Indianapolis to Columbus, Indiana, was built and operated for years by private capital charging the lowest rate in the state $-1 \frac{1}{2}$ cents per mile. It had outstanding bonds of $\$ 782,000$ and common stock of $\$ 910,000$. Its owners caused its common stock to be increased to $\$ 1,840,000$ and executed to the Interstate Public Service Company, a subsidiary of the Middle West Utilities Company, a lease for 999 years at $\$ 92,000$ a year. In addition, the Interstate Company paid a flat sum of about $\$ 600,000$ for the execu- 
tion of the lease for which it issued $\$ 616,000$ of the stock of the Interstate Company. What, if any, additional stock was issued by the Middle West Utilities Company on account of the transaction is not disclosed as the Middle West Company is beyond the jurisdiction of our state. There was, however, as a result of the entire transaction, over one and one-half million dollars added to the securities for which the particular utility is supposed to be responsible.

Since the transfer of the property an application has been filed with the Indiana Commission for an increase in rates. In neither one of these cases did a single dollar go into the treasury of the operating company, nor has the public received any benefit by way of reduced rates or improved service. I am somewhat familiar with the effect of holding company ownership and control in Indiana and the general rule has been largely to increase the volume of the securities of the various properties without any compensating benefit in the way of increased operating efficiency, reduced rates or improved service, except where small cities and towns have been connected with a central station, a practice rapidly increasing whether the utilities are controlled by a holding company or operated independently.

The price at which the securities of the holding company can be sold will be determined almost exclusively by the dividends paid upon the stocks of the subsidiaries, and, in order to find a market for its securities, the temptation will be ever present to strain every point to the declaration of the possible dividend upon the stocks of the subsidiaries in order to enhance the market value of its own securiti es. It cannot be said in answer to this that, by selling their securities, the dominant interests will lose control of the holding company. Experience has shown that a very small minority, concentrated in the hands of a few insiders, can control the conduct of any large corporation, if its stock ownership is widely distributed. The larger the corporation and the more widely the securities are scattered the more easily can this be accomplished. We may not unnaturally expect that at favorable times these secondary securities will be sold to the public and those who control the affairs of the holding company left with the minority interest.

Regulatory bodies up to this time have been slow to interfere with the rates of public utilities, but it is not unreasonable to expect they very soon will show a disposition to do so. This tendency will be more pronounced if experiments in municipal ownership, now 
under way, such as the Cleveland lighting plant and the quasi-public ownership of the Citizens Gas Company of Indianapolis, under what is known as the Potts plan, should prove successful and demonstrate that gas and electric current can be furnished permanently at the unusually low rates there obtaining.

That the finding of commissions affect the market value of the securities is demonstrated by Mr. Homer when he stated "That as the result of rate hearings in New York, the stock of two electrical companies dropped 25 per cent to 30 per cent, the dividends of one company was cut $33 \frac{1}{2}$; and of another entirely suspended, with a consequent hardship to the holders of those securities."

Should commissions, in the exercise of their power, attempt to reduce rates so as to impair the value of the securities of holding companies, then the public interest would become involved and the action of the commission would be influenced by the effect any decision they might render, would have on the value of the securities of the holding companies.

As these securities have been issued under the sanction of laws enacted by legislative bodies representing the people, commissions hesitate to adopt a rate that would largely impair and sometimes completely destroy their value.

The Commercial and Financial Chronicle, under date of October 24,1914 , urges the granting of the 5 per cent increase in freight rates and assigns as one of the reasons that from 15 per cent to 32 per cent of the assets of the savings banks and life insurance companies of the East and from 10 per cent to 20 per cent of the assets of our educational and benevolent institutions are invested in railway securities and that a failure to grant the increase would greatly injure these institutions.

It further urged the increase on the ground that vast sums of such securities are held abroad and a failure to grant the increase would impair the credit of the railways abroad and not only make it impossible to develop them so as to care for the expanding needs of the country, but that the credit of the whole country would be impaired by their failure to act favorably to the carrier.

The same influences will be at work on regulatory bodies should any widespread attempt be made to reduce public utility rates in our country and commissions, in adjusting rates, will be compelled to decide between the communities served by the utility, on the one 
hand, and the investors in these securities, on the other. Those who are now protesting most vigorously that the securities issued by holding companies can have no possible influence on commissions will then be asserting that any action that would in any way impair the value of such securities is not only inherently wrong, but would injure the general credit and retard for years the proper development of our public utilities.

While this argument has no sound foundation from a legal point of view it will appeal to the sense of fairness and conscience of the regulatory bodies and exert a potent influence on their decisions.

Again, the complexity of control exercised by the holding company tends to obscure the truth and make more difficult the regulation of rates. The question as to the proper amount to be charged against the operating company of overhead, supervision, legal expenses, interest charges and rental of appliances owned or controlled by the holding company, often necessitates an inquiry into the business of the holding company which is frequently without the jurisdiction of regulatory bodies. The public service commission of Massachusetts in the Middlesex and Boston rate case decided October 28, 1914, says:

Control of a street railway company or holding company which loans large sums to the street railway company which controls a company selling power to the street railway company and also owns a park company to which large annual payments are made by the street railway company is obnoxious to sound principles of corporation management and confusing to a proper regulation by this Commission. Such control and interlocking management calls in question the validity and advantages to the street railway company of all contracts made with the holding company or in any way growing out of the common control.

It is interesting to note that the commission found in this decision that the holding company which also controlled a park and amusement company, caused the operating company to make such substantial payments each year to the maintenance of the amusement and park company as to enable it to pay an average of $25.89 \%$ annual dividends upon its capital stock, while the operating company itself was only earning $4.59 \%$. The commission further found that the holding company was also charging its operating company $1 \frac{1}{2} \%$ to $2 \%$ interest in excess of the rates paid by the holding company. 
This situation is not peculiar to the Massachusetts case, but no doubt exists in many other instances, making the work of the regulatory bodies more difficult and confusing the issues involved in each case where the utility is being operated by a holding company.

It has been a common practice for holding companies to acquire a majority only of the stocks of the operating utility. This is a practice that should be absolutely prohibited. No corporation should ever be permitted to acquire a part of the property and then to use the whole of it in its own interest. A mere reference to the finding of the Massachusetts commission in the Middlesex and Boston case shows a few striking instances of how easy it is for a holding company to use a property for the benefit of itself and against the interests of the minority stockholders of the operating company.

We are told every day that business is being depressed and the proper development of our country retarded by the increasing tendency of state and national governments to interfere in the management of public service and other corporations.

Our public utility companies are not finished. They are in process; are constantly calling, and in increasing amounts, for new capital. They must be kept on good trading terms with the investing public, or the whole experiment of private ownership and public regulation will fail and the country be driven to public ownership, something to be avoided until such time, at least, as the administration of municipal affairs can be completely divorced from partisan politics. If regulation is to limit, as it should, the profits of shareholders, it should protect all investments honestly and prudently made or their will be no investment. If regulatory bodies, in the interest of the public, are to regulate and control all the securities issued by the utilities, then, in my opinion, that same public interest must in the end require the regulation and control of holding companies, whose sole business it is to operate these utilities, and issue and sell to the public, stocks and bonds based upon their securities. 